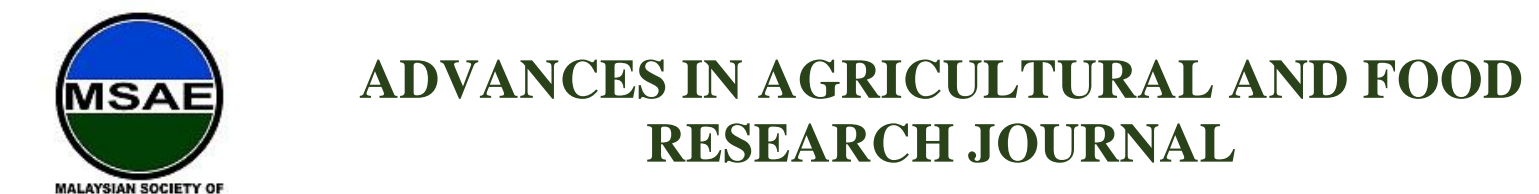

HH PUBLISHER

Short Communication

\title{
Effect of Mole Drain and Tracked Agricultural Prime Movers on Soft Soil Paddy Areas
}

\begin{abstract}
Ahmad Mohd Taufik ${ }^{1 *}$, Omar Mohamad Fakhrul Zaman², Md Isa Mohamed Fauzi ${ }^{3}$, Khadzir Mohd Khusairy ${ }^{3}$, Sharu Eddy Herman ${ }^{1}$, Aziz Mohd Hashim³ ${ }^{3}$ Othman Azlan ${ }^{3}$, Md Nor Saifulizan ${ }^{3}$, Abu Kasim Bunyamin ${ }^{1}$ and Norhafizi Mansor ${ }^{1}$

${ }^{1}$ Engineering Research Center, MARDI HQ, Serdang, Selangor, 43400 Malaysia, taufik@mardi.gov.my

${ }^{2}$ Engineering Research Center, MARDI Sintok, Kedah, 06500 Malaysia, fakhrulz@mardi.gov.my

${ }^{3}$ Engineering Research Center, MARDI Seberang Perai, Penang 13200 Malaysia, fauziisa@ mardi.gov.my

*Corresponding author: Ahmad Mohd Taufik, Engineering Research Center, MARDI HQ, 43400 Serdang Selangor, Malaysia; taufik@mardi.gov.my.
\end{abstract}

\begin{abstract}
Soft soil condition has become a major problem faced by Malaysian paddy farmers. MARDI has developed mole drain subsoiler and tracked agricultural prime movers to overcome this problem. The objective of this paper was to evaluate the effect of mole drain integration and tracked prime movers on soft soil area. The mole drain was installed on an identified soft soil area at an experimental plot at the Department of Agriculture (DOA) Station, Kg Bukit Merah, Seberang Perai Tengah, Penang. Tracked prime movers were used for land preparation, transplanting and harvesting. Soil strength data and rainfall were monitored and collected on a monthly basis, using penetrologger and weather station, respectively. Results showed that the soft soil condition of the plot was reduced to from $79 \%$ to $17 \%$, corresponding to a reduction of $62 \%$. This shows that mole drain system and tracked agricultural prime movers have the potential to reduce soft soil problem in paddy fields.
\end{abstract}

Keywords: mole drain; half-tracked prime movers; soft soil; paddy fields

Received: $29^{\text {th }}$ March 2021

Received in revised form: $18^{\text {th }}$ June 2021

Citation: Taufik, A. M., Zaman, O. M. F., Fauzi, M. I. M., et al. Effect of mole drain and tracked agricultural prime movers on

Accepted: $13^{\text {th }}$ July 2021

soft soil paddy areas. Adv Agri Food Res J

2021; 2(2): a0000228.

Available Online: $23^{\text {rd }}$ July 2021 https://doi.org/10.36877/aafrj.a0000228

\section{Introduction}

Soft soil condition has become a major issue faced by paddy farmers (Taufik et al., 2015). Soft soil is defined as an area with low and inadequate bearing capacity, having less than 0.3 MPa at $30 \mathrm{~cm}$ depth, to support the agricultural machineries on it (Ahmad et al., 2020; Fauzi et al.,2018; Rendana et al., 2017; Nordin et al., 2014). In 2013, 8000 hectares of soft soil areas were identified in MADA, 4800 hectares in KETARA and 5200 hectares in IADA Kemasin Semerak (Abdullah, 2014). 
Soft soil condition is caused by imperfect drainage system, stagnant water and uneven surfaces that prevent paddy fields from drying continuously in 9 days after paddy harvesting. Soil hardpan layer usually will try to recover or reform during this stage (Sharu et al., 2016). Since good drainage is key to ensuring paddy field can be dried properly, two methods are available, which is surface drainage and sub-surface drainage.

Another issue that also causes soft soil condition is heavy machinery. Soil hardpan layer is required in paddy fields to support the weight of field machineries for mobility (Ahmad et al., 2020; Hemmat \& Taki, 2003). The use of pneumatic rubber tires, which produces high ground contact pressure, is claimed to cause damage to the soil hardpan layer. The usage of tractors and combine harvesters weighing more than 5 tons have also created heavy pressure to the soil surface (Ahmad et al., 2020; Vial et al., 2020)

MARDI has developed a few technologies to overcome this problem, namely mole drain subsoiler and low ground pressure, tracked prime movers. These technologies were developed as solutions for soft soil problem specifically in paddy fields.

Mole drain subsoiler was developed by Sharu et al. (2016) and further improved by Omar et al. (2020). The mole drain is a tractor-mounted implement which comprises of a steel frame, cutting blade, mole channel, and rope application. Its main function is to channel standing water from inside of the plot to the outlet drainage using an absorption method using rope. The furrow or mole opener would create a hole of up to $45 \mathrm{~cm}$ deep, big enough for jute or rice-straw based rope to be installed together in one operation. In addition, Omar et al. (2020) reported on the positive effect of using this technique to reduce the soft soil problem.

Tracked agricultural prime movers were developed by Taufik et al. (2014). This group of technology included 4 half-tracked tractors, rear half-tracked paddy transplanter and a 4 half-tracked high clearance lightweight tractor (Sayuti et al., 2017). A combine harvester equipped with 4 half-tracks was also developed to overcome soft soil problem (Taufik et al., 2015). This technology provides a solution by increasing the ground contact area to reduce the contact pressure onto the soil.

There is a need to integrate these two technologies to observe the effect on soil hardpan layer and to observe the mechanized paddy production using tracked prime movers. The objective of this paper is to evaluate the effect of integrating mole drain and tracked prime movers on soft soil area.

\section{Materials and Methods}

The experiment was conducted at a specific location at Department of Agriculture (DOA) Station, Kg Bukit Merah, Seberang Perai Tengah, Penang. The experimental plot was $145 \mathrm{~m}$ long, $50 \mathrm{~m}$ wide, and identified as a problematic area with soft soil problem (DOA, personal communication, March 2018). Initial soil strength data was measured and collected in March 2018 up to 80cm depth using a soil cone penetrometer (Penetrologger, Eijelkamp, 
The Netherlands) with a base area of $323 \mathrm{~mm}^{2}$. After secondary tillage, mole drain system was installed using a jute rope, which came in $150 \mathrm{~cm}$ roll with $35 \mathrm{~mm}$ diameter, at $45 \mathrm{~cm}$ depth using a mole plough subsoiler (Figure 1). This depth was chosen based on the method used by Sharu et. al. (2016) where the depth was lower than the soil hardpan layer (which is located at $30 \mathrm{~cm}$ depth) and prevents damage of the mole drain system during ploughing, which occurs in the 20 to $30 \mathrm{~cm}$ depth zone. The rope was installed at a distance of $12 \mathrm{~m}$ apart. Grid based soil strength data of $10 \mathrm{~m}$ by $10 \mathrm{~m}$, which accumulates to 75 points, with 3 replications for each point, were collected every month. (Figure 2)

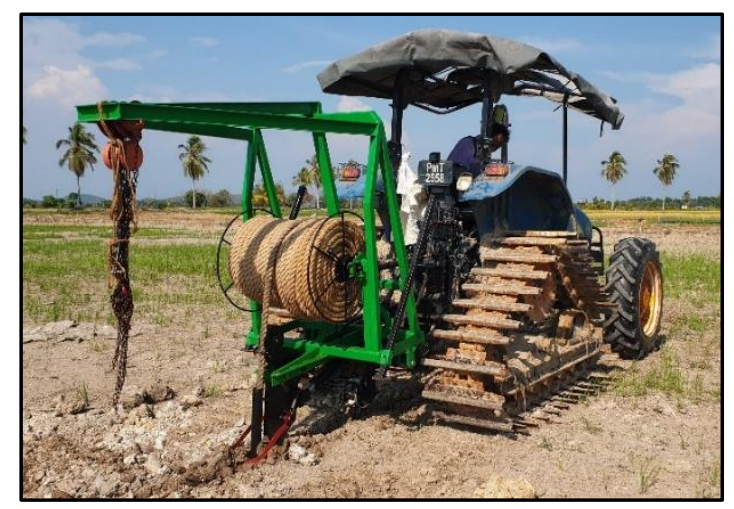

Figure 1. Mole plough subsoiler used to install mole drain system using jute rope.

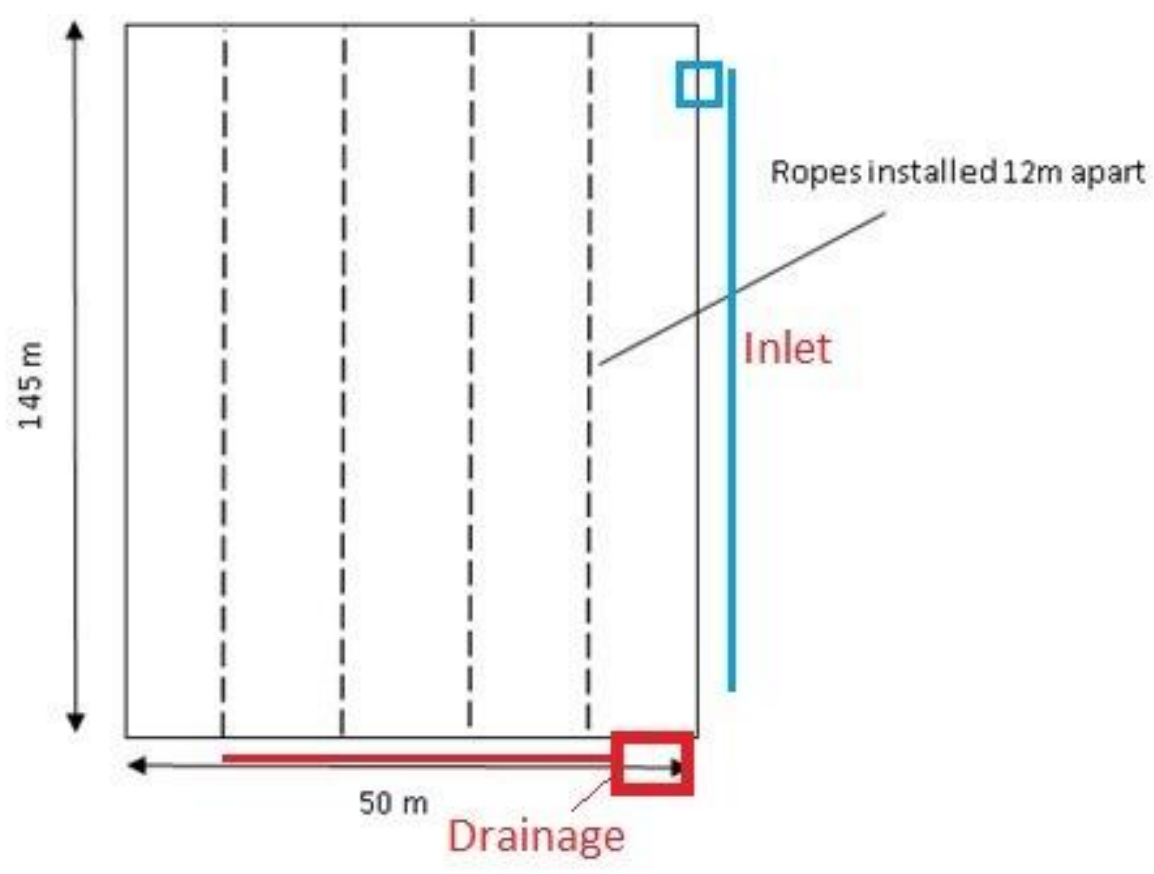

Figure 2. Layout of mole drain system used in the experiment.

\subsection{Paddy Cultivation}

After applying the subsoiler, a rotor tiller was attached to a 4 half-tracked tractor via PTO (power take-off) to till the soil before transplanting can be done. A transplanter with 
rear half-tracks was used for paddy transplanting. After around 100 days, paddy was harvested using a mini combine harvester (DC-60G, Kubota) (Figure 3).

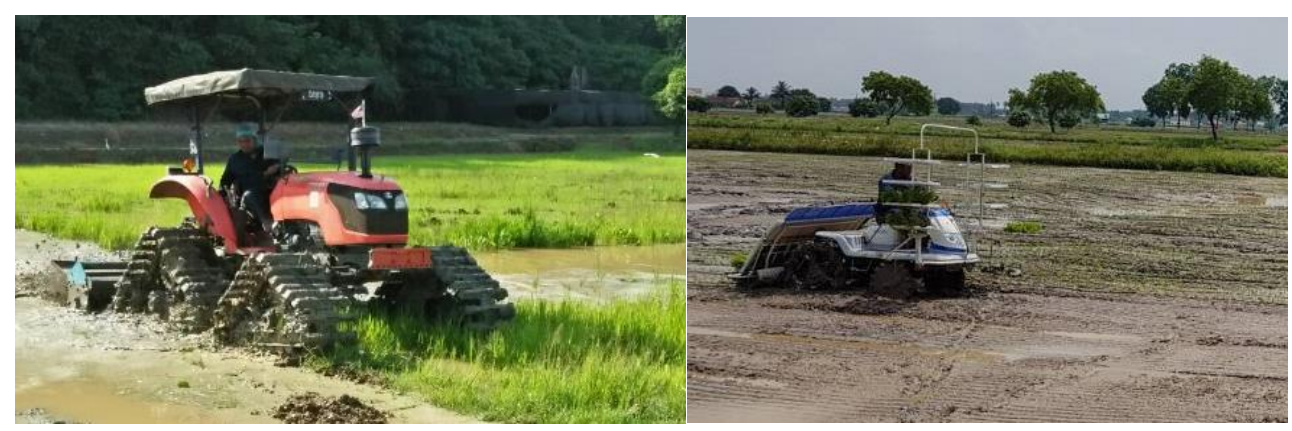

(a)

(b)

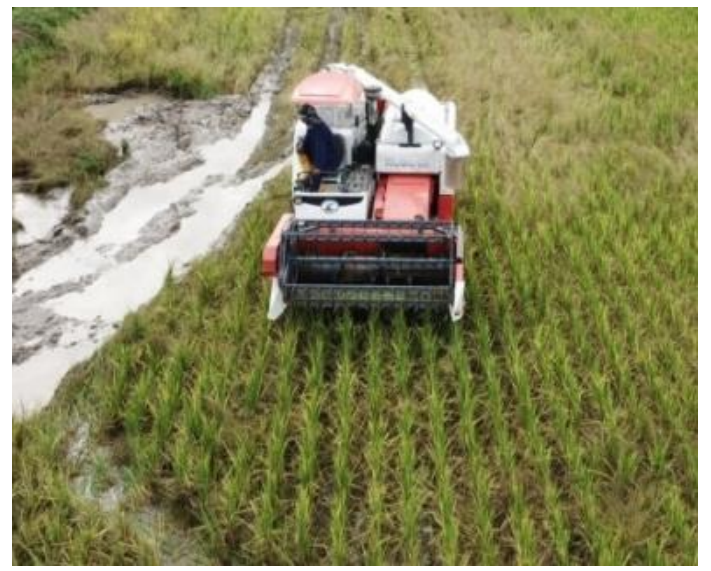

(c)

Figure 3. (a) Quad-Track tractor with rotor tiller; (b) Half-Track transplanter, and (c) mini combine harvester that was used throughout the experiment.

\subsection{Weather Data}

During the duration of the experiment, rainfall data was taken from the MARDI Seberang Perai weather station (Vantage Pro 2, Davis Instruments, USA), which is located $15 \mathrm{~km}$ radius from the experiment location. Daily rainfall data was monitored and collected.

\subsection{Contour Mapping}

Contour mapping software (Surfer, USA) was used to create a soil strength map at 30 $\mathrm{cm}$ depth. Since the penetrologger data was taken in a monthly interval, the contour map was also generated and monitored monthly.

\subsection{Statistical Analysis}

Statistical analyses were done with SAS statistical software (SAS, USA) using means comparison t-test comparing soil strength data before and after integration of mole drain system and tracked prime movers. T-test results and standard deviation (SD) were reported. 


\section{Results and Discussions}

The initial soil strength condition of the experimental plot showed that $79 \%$ of the plot showed values of less than 0.3 MPa. This was the reason why DOA considered this plot to be a soft soil area, in addition to the bogging down of heavy machinery during paddy cultivation.

\subsection{Contour Map}

After applying the mole drain subsurface drainage, soil strength was monitored after tillage, transplanting, and finally during crop harvesting. The results after two harvesting seasons showed significance increase of soil strength data, which in turn reduced the soft soil problem from $79 \%$ to $17 \%$. This indicates a significant reduction of $62 \%(t=-11.23, p$ $=0.0001)$ (Figure 4).

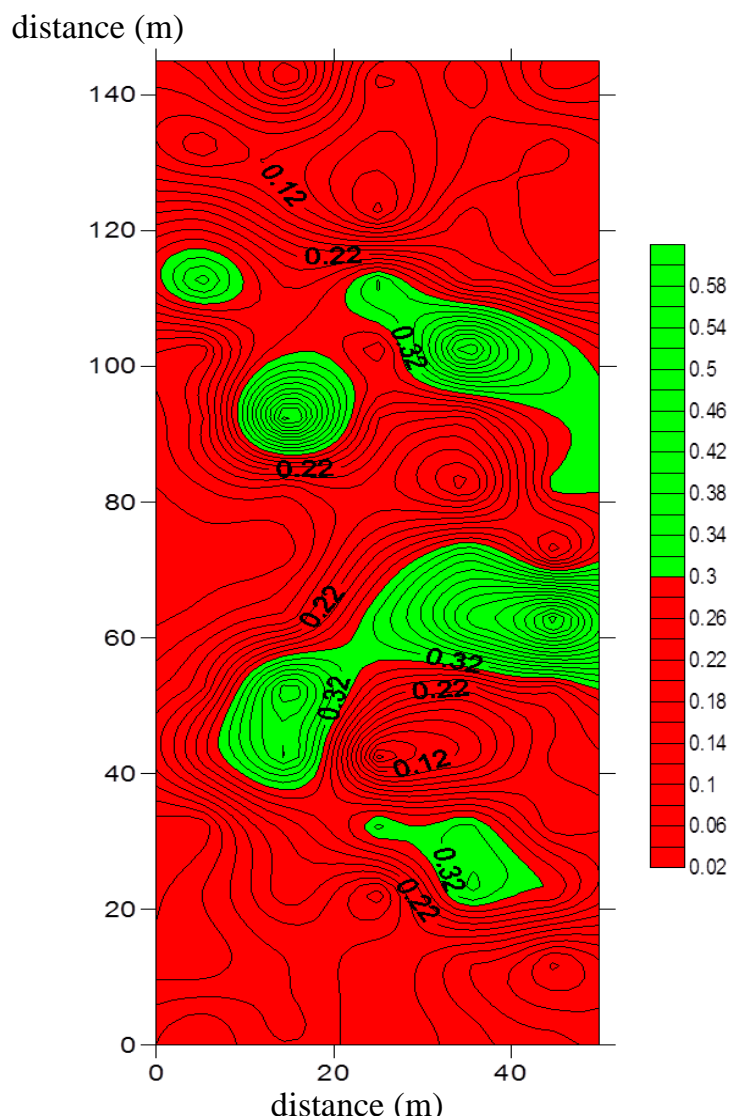

(a)

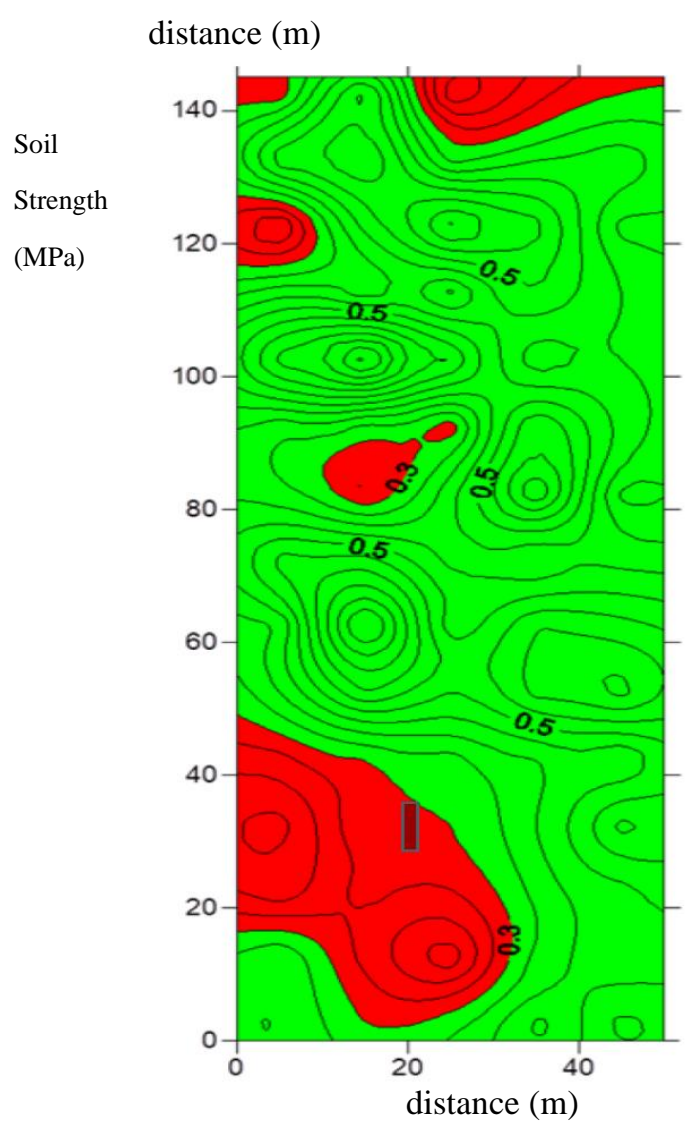

(b)

Figure 4. Contour map of the plot at $30 \mathrm{~cm}$ depth, (a) before and (b) after integration of mole drain system and tracked prime movers $(\mathrm{n}=75, \mathrm{SD}=0.1864)$. Red coloured regions indicate soft soil (soil strength less than $0.3 \mathrm{MPa}$ ), while green coloured regions indicate no soft soil.

\subsection{Weather Data}

Average rainfall throughout the duration of the experiment was $173.6 \mathrm{~mm}$ $(\mathrm{SD}=116.19)$ with the highest rainfall of $358.2 \mathrm{~mm}$ in May 2018 and the lowest rainfall of 
$12.8 \mathrm{~mm}$ in February 2019. When combined with the rainfall distribution data, reduction of soft soil was related. (Figure 5) The soft soil occurrence was shown to gradually decrease when the monthly rainfall was below $300 \mathrm{~mm}$. Usually during the main season, which is from March to August, the average rainfall is higher than the off season. This period is usually the period where the soft soil occurrence is very high; hence, it is really important to manage the soil hardpan layer during this period. The off season (October to January) is usually the recovery period for the soil hardpan layer and with the help of the mole drain system, the soft soil occurrence inside the plot was drastically decreased.

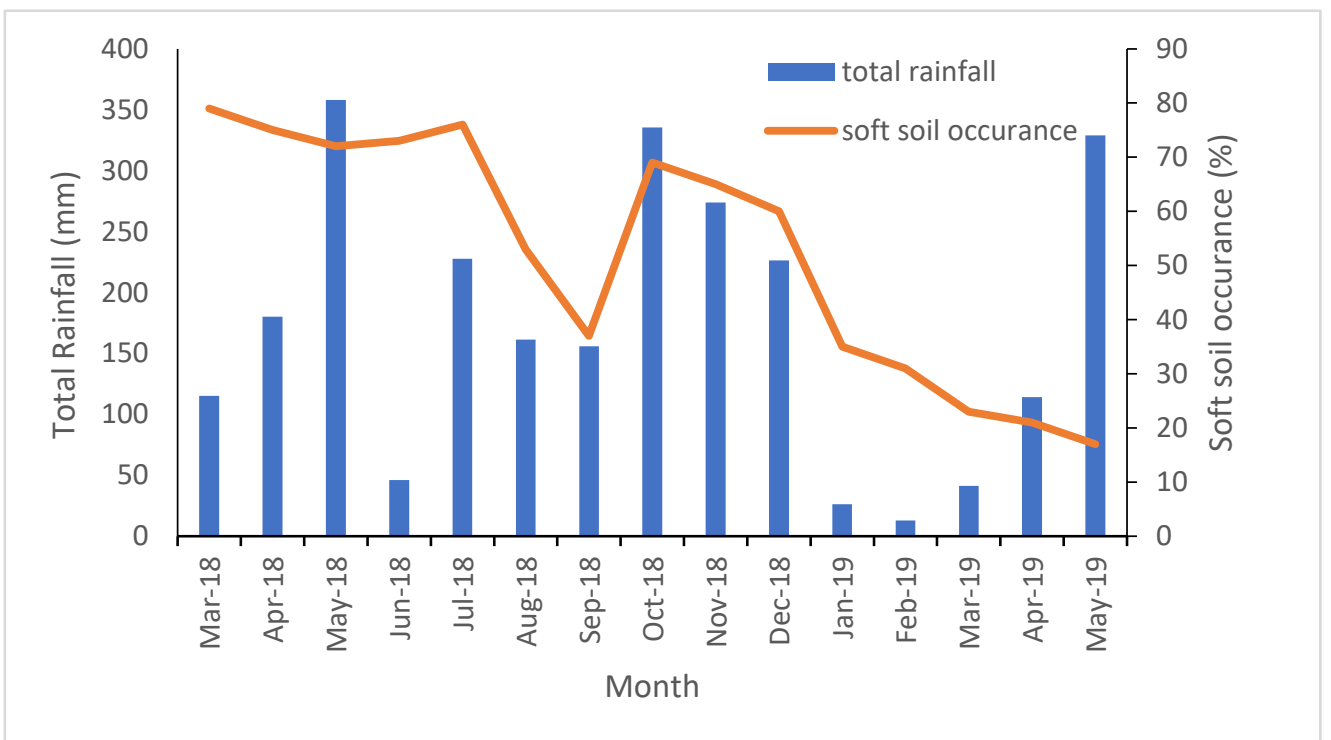

Figure 5. Soft soil occurrence based on monthly rainfall distribution. Main season was from May 2018 to August 2018. The off season was from October 2018 to January 2019.

\subsection{Soil Strength Data}

The effects on soil strength after the use of both technologies in two harvesting seasons was significant $(t=10.71, p=0.0001)$. This showed that the mole drain system has successfully drained the standing water from inside the paddy field to the exit drainage. The use of low ground contact pressure prime movers has also helped in maintaining and preserving the soil hardpan layer to ensure machinery mobility in the field. Soil strength increased to $50 \%$ was observed at $30 \mathrm{~cm}$ depth after the use of both technologies. A case study conducted by Fauzi et al. (2015) in comparing the usage of mole drain system with a corrugated piping system and sub-surface drainage system, showed that the mole drain system was the best and fastest method to remove excess water from inside the plot to the outlet drainage. 


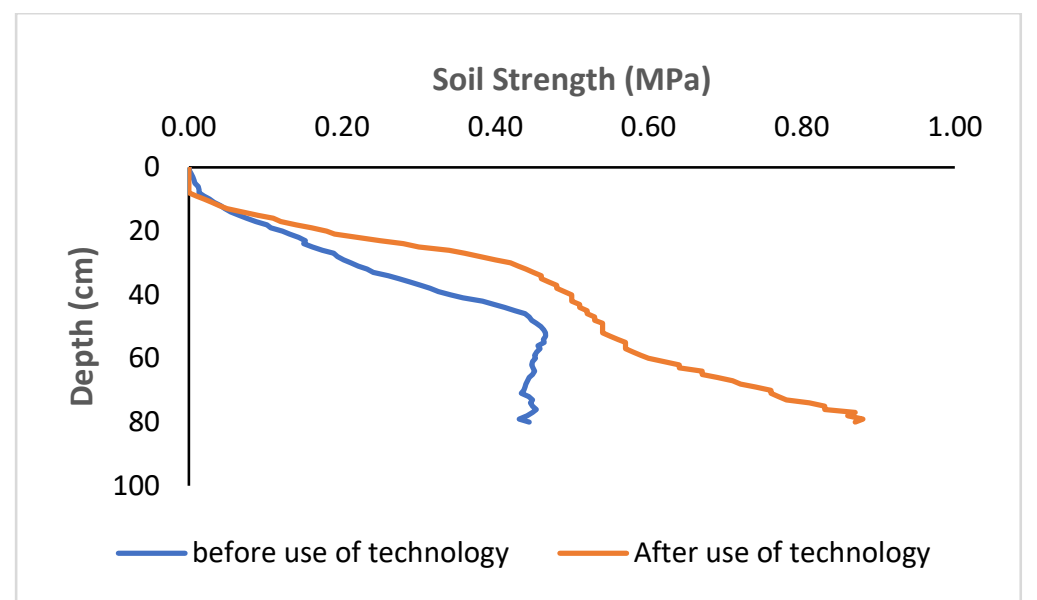

Figure 6. Average soil strength of up to $80 \mathrm{~cm}$ depth, before and after integration of mole drain system and tracked prime movers. $(\mathrm{n}=81, \mathrm{SD}=0.122)$.

\section{Conclusions}

The results showed that by integrating the mole drain subsoiler and agricultural tracked prime movers resulted in the decrease in soft soil problem. . The soft soil condition was found to have been reduced from $79 \%$ to $17 \%$. Hence, the plot could be cultivated during the whole period. It is essential to manage the soil hardpan layer in paddy fields to ensure mechanization become sustainably possible. The application of these two technologies together will help to improve paddy cultivation. Future study that can be done is to test these two technologies in other granary areas that have soft soil conditions such as MADA (Muda Agricultural Development Authority), KADA (Kemubu Agricultural Development Authority) and IADAs (Integrated Agricultural Development Authority).

Author Contributions: "Methodology, MTA, MFZO, MFMI, MKK, EHS; software, MFMI, MFZO.; investigation, MTA, MFZO, MFMI, MKK, EHS, MHA, AO, SMN, BAK, NM; data analysis, MTA, MFZO, MFMI, MKK, EHS.; writing — original draft preparation,MTA; writing-review and editing, MFZO, MFMI, MKK, EHS.;

Acknowledgments: The researchers would like to express gratitude to Kg Bukit Merah Station, Department of Agriculture (DOA) for providing the experimental plot. The researchers would also like to thank the Engineering Research Center staffs form MARDI Seberang Perai and MARDI Headquarters for their assistance throughout the experiment.

Conflicts of Interest: The authors declare no conflict of interest.

\section{References}

Abdullah, N. (2014). Approaches to Overcome Soft Soil Problem in Muda Area. In Proceedings of National Conference on Agricultural and Food Mechanization (p. 162).

Ahmad, M., Khadzir, M., Omar, M. (2020). Performance of a Triangular Rubber Tracked Tractor in Paddy Fields. Advances in Agricultural and Food Research Journal, 1(2), 1-7. https://doi.org/10.36877/aafrj.a0000132

Hemmat, A., Taki, O. (2003). Comparison of compaction and puddling as pre-planting soil preparation for 
mechanized rice transplanting in very gravelly Calcisols in central Iran, 70, 65-72.

Fauzi, M. I. M., Padzil, A. R. M. N., Chan, C. S., et al. (2018). Effects of Five Seasons in Two Years Paddy Planting Programme on Soil Bearing Capacity. Journal of Built Environment, Technology and Engineering, 4(May 2018), 252-257. Retrieved from http://www.jbete.com/wpcontent/uploads/2018/05/JBETE4_90-92.pdf

Fauzi, M. I. M., Chan, C. S., Herman, S. E., et al. (2015). Soft Soil Study in BUkit Jambul Pendang MADA. Proceedings of National Plantation Industry Conference and Exhibition (NAPICEX 2015).

Nordin, M. N., Hamid, A. A., Sharu, E. H., et al. (2014). Kaedah penggantian tanah untuk meningkatkan kekuatan struktur tanah di kawasan tanah jerlus. Jurnal Teknologi, 70(6), 45-47. https://doi.org/10.11113/jt.v70.3536

Omar, M. F. Z., Sharu, E. H., Ahmad, M. T., et al. (2020). The application of mole plough with rope applicator to reduce soft soil problem in rice field. International Journal of Agriculture, Forestry and Plantation, $10,345-348$.

Rendana, M., Idris, W. M. R., Rahman, Z. A., et al. (2017). Effect of Hasil Tani Organic Compound product ( HTOC ) on the recovery of soft soil in rice field, $l$ (September 2016), 13-20.

Sayuti, A. F. A., Ahmad, M. T., Rani, R. A., et al. (2017). Mesin Penanam Padi dan Traktor Berkelegaan Tinggi Menggunakan Sistem Trek Separa Rantai Untuk Mengatasi Permasalahan Tanah Jerlus di Sawah Padi Malaysia. In Persidangan Padi Kebangsaan 2017 (pp. 1-4). MARDI.

Sharu, E. H., Nordin, M. N., Fauzi, M. I. M., et al. (2016). Effect of Subsurface Drainage on Soil Hardpan Layer in Soft Soil Area. In Soil Science Conference of Malaysia 2016. MSSS.

Taufik, A. M., Khusairy, K. M., Fauzi, M. I. M., et al. (2015). Performance of a Quad-Steel Tracked Tractor on Paddy Field. In Malaysian Soil Science Conference. Malaysian Soil Science Society (MSSS).

Taufik, A. M., Khusairy, K. M., Fauzi, M. I. M., et al. (2014). Preliminary Trial of A Quad-steel Tracked Tractor on Paddy Field. In Proceedings of National COnference on Agricultural and Food Mechanization (pp. 130-133).

Vial, L. K., Molesworth, A., Lefroy, R. D. B. (2020). Balancing rice and non-rice crops: Managing the risks from soil constraints in Mainland Southeast Asian rice systems. Field Crops Research, 246(November 2019), 107677. https://doi.org/10.1016/j.fcr.2019.107677 